\title{
ファジィパラメータを含む多目的非線形計画問題 に対する対話型意思決定
}

\author{
坂 和 正 敏*·矢 野均** \\ Interactive Decision Making for Multiobjective Nonlinear \\ Programming Problems with Fuzzy Parameters \\ Masatoshi SAKawa* and Hitoshi Yano**
}

This paper presents a new interactive decision making method for multiobjective nonlinear programming problems with fuzzy parameters. The fuzzy parameters involved in objective functions and constraints are characterized by fuzzy numbers. The concept of $\alpha$-Pareto optimality is introduced in which the usual Pareto optimality is extended based on the $\alpha$-level sets of fuzzy numbers. In our interactive decision making method, if the decision maker (DM) specifies his reference objective values and the degree $\alpha$ of the $\alpha$ level sets, the minimax problem is solved and the DM is supplied with the corresponding $\alpha$-Pareto optimal solution together with the trade-off rates among the values of the objective functions and the degree $\alpha$. Then by considering the current values of the objective functions and $\alpha$ as well as the trade-off rates, the DM responds by updating his reference objective values and/or the degree $\alpha$. In this way, the satisficing solution for the DM can be derived efficiently from among an $\alpha$-Pareto optimal solution set.

Key Words : multiobjective nonlinear problems with fuzzy parameters, fuzzy numbers, level set, $\alpha$-Pareto optimal solution, Interactive decision making

\section{1.はじめに}

一般に，現実のシステムをモデル化した多目的意思 決定問題に対して, 意思決定者 (Decision Maker :

* 神戸大学工学部 神戸市灘区六甲台町 1-1

** 香川大学経済学部 高松市幸町 2-1

* Faculty of Engineering, Kobe University, Kobe

** College of Economics, Kagawa University, Takamatsu

(Received February 20, 1985)

(Revised October 30, 1985)
DM）の選好を最もよく反映させた解を何らかの多目 的意思決定手法により導出した場合, 得られた解は, 残念ながら，必ずし屯現実の意思決定状況における DM の真の選好解であるとは限らない. 定式化された 多目的意思決定問題を解いて求められた DM の選好 を反映した解と，実システムに対する DM の真の選 好解との間に，乙のようなギャップが生ずる原因は， 主としてつぎの 2 種類のあいまい性によるあのと考え られる。

（1） DM の選好順序に関するあいまい性

（2）実システムに対する数式モデルを決定する際 に生じるあいまい性

これらのあいまい性のうち，（1）に対しては，DM の代替案に対する判断のあいまい性を考慮したファジ ィ線形計画法が Zimmermann'1) により提案され, 発 展してきている ${ }^{2)-6)}$. 一方 (2)に対しては, 各目的関 数や制約式の係数にあいまい性が含まれているような 問題を定式化することにより，実システムをより正確 に近似するモデルが得られるあのと期待できる. この ようなシステム自体に含まれるあいまい性に対処する ため, 田中ら ${ }^{71,8)}$ は, 線形の制約条件と線形の目的関 数における係数が台形のファジィ数で表わされるよう な線形のモデルに対して，ファジィ線形計画問題とし ての定式化を試みた，彼らは，係数のあいまい性を考 慮した非ファジィな解を求める場合のみならず，係数 のあいまい性を反映してどれくらいあいまいな決定を することができるかという場合に対しても考察してい る. しかし, 対象とする問題は線形の場合のみに限ら れており, 非線形への拡張が望まれていた。近年, Orlovski ${ }^{9)}$ は, 多目的非線形計画問題に対して, 制約 条件と目的関数における係数がファジィ数として特徴 づけられる場合について考察したが，残念ながら，係 数のあいまい性をあ考慮して DM の妥協解を求める 
ための具体的な対話型アルゴリズムは提案されていな い.

このような状況において，本論文では，実システム に対して数式モデルを決定する際に生じるあいまい性 に対処するために，係数がファジィ数で表わされる多 目的非線形計画問題を取り扱い，係数のあいまい性を あ考慮した新しい解の概念として， $\alpha$-パレート最適解 を定義して， $\alpha$-パレート最適解の集合の中から DM の満足解を導出するための対話型意思決定手法を提案 する. さらに, 提案した手法の数值例への適用が示さ れる.

\section{2. a-パレート最適解}

一般に, 多目的非線形計画 (Multiobjective Nonlinear Programming: MONLP) 問題はベクトル最小 化問題として次のように定式化される.

\section{MONLP}

$$
\left.\begin{array}{l}
\min _{x} f(x) \triangleq\left(f_{1}(x), f_{2}(x), \cdots, f_{k}(x)\right)^{T} \\
\text { subject to } \\
x \in X \triangleq\left\{x \mid x \in R^{n}, g_{j}(x) \leqq 0, j=1,2, \cdots, m\right\}
\end{array}\right\}
$$

しかし，てのように数学的に定式化された MONL$\mathrm{P}$ には，本来，実システムのモデル化の際に生じるあ いまい性が含まれているあのと考えるととが妥当であ ろう. このようなあいまい性は各々の目的関数亡制約 式の係数に反映されているとの観点から, 各々の目的 関数之制約式の係数のあいまい性がファジィ数として 表わされているようなあいまいな係数を含む多目的非 線形計画問題を考え，乙こではファジィ多目的非線形 計画問題 (Fuzzy MONLP: FMONLP) と呼び,つ ぎのように定式化する.

\section{FMONLP}

$\min f(x, \tilde{a}) \triangleq\left(f_{1}\left(x, \tilde{a_{1}}\right), f_{2}(x, \tilde{a}), \cdots, f_{k}\left(x, \tilde{a}_{k}\right)\right)^{T}$ subject to

$\left.x \in \tilde{X} \triangleq\left\{x \mid x \in R^{n}, g_{j}\left(x, \tilde{b}_{j}\right) \leqq 0, j=1,2, \cdots, m\right\}\right\}$

以下では, 簡単のため, $\tilde{a}_{2}$ は $i$ 番目の目的関数に含 まれるファジィ数として表わされる係数全体のベクト ルを示し，同椂に $\tilde{b}_{j}$ は $j$ 番目の制約式に含まれるフ アジィ数として表わされる係数全体のベクトルを示す あのとする. 即ち $\tilde{a}_{i}=\left(\tilde{a}_{i 1}, \cdots, \tilde{a}_{i p_{i}}\right), \tilde{b}_{j}=\left(\tilde{b}_{j 1}, \cdots, \tilde{b}_{j q_{j}}\right)$ である.

ことで，(2)式で定式化されるファジィ多目的非線 形計画問題において, 各々の目的関数や制約式に含ま れる係数がすべてファジィ数で与えられているとは限 らない（即ち, ファジィ数で表わされる係数と通常の

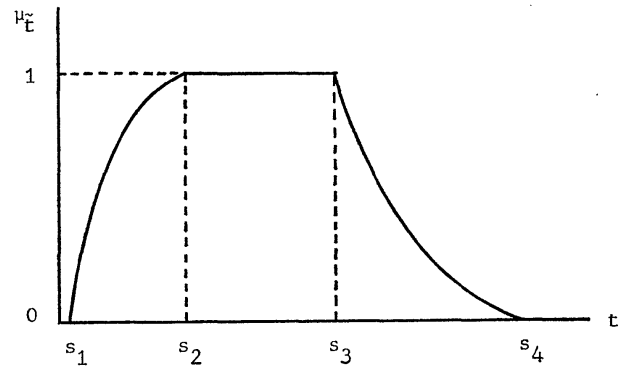

Fig. 1 Fuzzy number

数で表わされる係数が混在している場合あ対象として いる）ととに注意しよう.

本論文を通して用いられるファジィ数は, Dubois とPrade ${ }^{10), 11)}$ により導入されたあのであるが，つぎ の性質を満たしているすのとする. 即ち, ファジィ数 $\tilde{t}$ のメンバシップ関数を $\mu_{z}(t)$ で表わせば, $\mu_{z}(t)$ は次 の性質を持つ. (Fig. 1 参照)

（1） $\mu$ は実数直線 $R^{1}$ から閉区間 $[0,1]$ への連続 写像

(2) $t \in\left(-\infty, s_{1}\right]$ のとき, $\mu_{t}(t)=0$.

(3) $t \in\left[s_{1}, s_{2}\right]$ のとき, $\mu_{\tilde{t}^{\prime}}(t)>0$.

(4) $t \in\left[s_{2}, s_{3}\right]$ のとき, $\mu_{z}(t)=1$.

(5) $t \in\left[s_{3}, s_{4}\right]$ のとき, $\mu_{t^{\prime}}(t)<0$.

(6) $t \in\left[s_{4}, \infty\right)$ のとき, $\mu_{t}(t)=0$.

(2) 式で定義されているファジィ多目的非線形計画 問題は, 各々の目的関数や制約式の係数がファジィ数 として特性づけられているため, これまでの通常の多 目的非線形計画問題に対して定義されてきた，いわゆ る, パレート最適解の概念をそのまま適用するととは できない. したがって，本論文では，通常のパレート 最適解の概念を拡張して, 問題に含まれるあいまい 性をも考慮したパレート最適解として, 新たに $\alpha$-パ レート最適解の概念を導入する. そのための準備とし て,まず,ファジィ多目的非線形計画問題 (2) に含まれ るファジィ数 $\tilde{a}_{i r}, \tilde{b}_{j_{s}}$ のメンバシップ関数をそれぞれ $\mu \tilde{a}_{i r}\left(a_{i_{r}}\right), \mu \tilde{b}_{j_{s}}\left(b_{j_{s}}\right)$ で表わし， $\alpha$ レベル集合11)をつぎの ように定義する. ことで $a_{i}=\left(a_{i}, \cdots, a_{i p_{i}}\right), b_{j}=\left(b_{j 1}\right.$. $\left.\cdots, b_{j q_{j}}\right), a=\left(a_{1}, \cdots, a_{k}\right), b=\left(b_{1}, \cdots, b_{m}\right)$ である.

[定義 1]（ $\alpha$ レベル集合：L( $L))$

$\alpha$ レベル集合 $L(\alpha)$ とは, 次式で定義される係数空 間の集合である.

$$
\begin{aligned}
& L(\alpha) \\
& =\left\{(a, b) \mid \mu \tilde{a}_{i r}\left(a_{i r}\right) \geqq \alpha\left(i=1, \cdots, k ; r=1, \cdots, p_{i}\right),\right. \\
& \left.\mu \tilde{b}_{j_{s}}\left(b_{j_{s}}\right) \geqq \alpha\left(j=1, \cdots, m ; s=1, \cdots, q_{j}\right)\right\}
\end{aligned}
$$

定義から明らかなように， $\alpha$ レベル集合 $L(\alpha)$ は，フ 
アジィ数として表わされているすべての係数の属する 度合いが $\alpha$ 以上であるような，パラメータ $\alpha$ に依存 した集合であり，つぎの性質をむつことは直ちにわか る.

\section{[性質 1]}

$\alpha^{1}<\alpha^{2}$ ならば $L\left(\alpha^{1}\right) \supset L\left(\alpha^{2}\right)$

ここで, FMONLP(2) に含まれるファジィ数に対 して，DM が主観的に，その属する度合が $\alpha$ 以上で あれば任意の值でよいと判断したと仮定しよう（以下 ではこの $\alpha$ の值を許容レベル值と呼ぶことにする). このとき, FMONLP (2) は係数べクトル $(a, b) \in$ $L(\alpha)$ をパラメータとするつぎのような通常の多目的 非線形計画問題 $\operatorname{MONLP}(a, b)$ として定式化できる.

\section{MONLP $(\boldsymbol{a}, \boldsymbol{b})$}

$\min _{x} f(x, a) \triangleq\left(f_{1}\left(x, a_{1}\right), f_{2}\left(x, a_{2}\right), \cdots, f_{k}\left(x, a_{k}\right)\right)^{T}$

subject to

$$
\left.x \in X(b) \triangleq\left\{x \mid g_{j}\left(x, b_{j}\right) \leqq 0, j=1,2, \cdots, m\right\} \quad\right\}
$$

しかし，このような多目的非線形計画問題 MONLP $(a, b)$ はパラメータ $(a, b) \in L(\alpha)$ に依存して無数に存 在する. したがって本論文では，乙のような MONLP $(a, b)$ のうち, パラメータ $(a, b)$ の值を DM に対し て最あ有利になるように設定する問題と解釈できる， つぎのような $\alpha$ レベル多目的非線形計画問題 $(\alpha-\mathrm{MO}$ NLP) を導入する.

\section{$\alpha$-MONLP}

$$
\begin{aligned}
& \min _{x, a, b} f(x, a) \triangleq\left(f_{1}\left(x, a_{1}\right), f_{2}\left(x, a_{2}\right), \cdots, f_{k}\left(x, a_{k}\right)\right)^{T} \\
& \text { subject to } \\
& \quad x \in X(b) \triangleq\left\{x \mid g_{j}\left(x, b_{j}\right) \leqq 0, j=1,2, \cdots, m\right\} \\
& \quad(a, b) \in L(\alpha)
\end{aligned}
$$

したがって， $\alpha$-MONLP（6）においては，係数べ クトル $(a, b)$ は，むはや，係数としてではなく変数 としての取り扱いを受けているととに注意しよう.

さて，通常のパレート最適解の概念を素直に拡張す るととにより， $\alpha$-MONLP (6) に対してつぎのよう な $\alpha$-パレート最適解を定義するととができる.

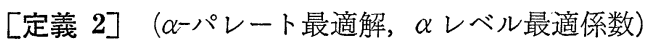
$\alpha-\operatorname{MONLP}(6)$ に対して, $f(x, a) \leq f\left(x^{*}, a^{*}\right)$ と なる $x \in X(b),(a, b) \in L(\alpha)$ が存在しないとき， $x^{*}$ を $\alpha$-パレート最適解と呼び, 対応する係数值 $\left(a^{*}, b^{*}\right)$ を $\alpha$ レベル最適係数と呼ぶ.

ここで， $\alpha-\operatorname{MONLP}(6)$ に対する $\alpha$-パレート最適 解と $\alpha$ レベル最適係数の意味について考えてみよう. FMONLP (2) 亿含まれるファジィ数として表わされ
る係数は， $\alpha$-MONLP においては，そのメンバシッ プ值が $\alpha$ 以上であれば自由に動くことができるから， むとの $\operatorname{MONLP}(1)$ と比較して, 問題を定式化する 際に生じるあいまい性を反映した解を得ることが可能 になるあのと思われる，乙こで，あいまい性の許容度 $\alpha$ は DM により主観的決定されるあのである．即 ち, $\alpha$-MONLP (6) において決定変数を $(x, a, b)$ と みなした時の通常の意味でのパレート最適解 $\left(x^{*}, a^{*}\right.$, $\left.b^{*}\right)$ に対して， $x^{*}$ が $\alpha$-パレート最適解であり，( $a^{*}$, $\left.b^{*}\right)$ が $\alpha$ レベル最適係数である.

ここで定義された $\alpha$-パレート最適解， $\alpha$ レベル最 適係数は， $\alpha$-MONLP（6）において，決定変数を $(x, a, b)$ とみなすととにより, 通常のパレート最適解 を得るための手法をそのまま直接適用して求めること が可能であるととに注意しよう。ここでは，非凸性を 含む問題に対してあ有効であるつぎの形式のミニマッ クス問題 $P_{\infty}(\hat{f}, \alpha)$ を利用するととにしよう.

$$
\begin{aligned}
& \boldsymbol{P}_{\infty}(\hat{\boldsymbol{f}}, \boldsymbol{\alpha}) \\
& \min _{x, z, a, b} z \\
& \text { subject to }
\end{aligned}
$$

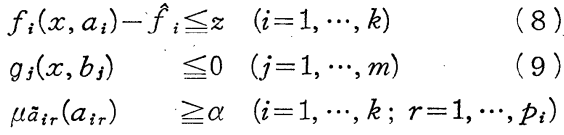

$$
\begin{aligned}
& \mu_{b_{j s}}\left(b_{j_{s}}\right) \quad \geqq \alpha \quad\left(j=1, \cdots, m ; s=1, \cdots, q_{j}\right)
\end{aligned}
$$

ここで, $\hat{f}=\left(\hat{f}_{1}, \hat{f}_{2}, \cdots, \hat{f}_{k}\right)$ は与えられた基準目的関 数值である. この時, 次の定理が成立する.

\section{[定理 1]}

$x^{*},\left(a^{*}, b^{*}\right)$ がそれぞれ $\alpha$-MONLP の $\alpha$-パレート 最適解, $\alpha$ レベル最適係数であるための必要十分条件 は， $x^{*},\left(a^{*}, b^{*}\right)$ が， ある $\hat{f}_{i}(i=1, \cdots, k)$ に対する $P_{\infty}$ $(\hat{f}, \alpha)$ の一意的な最適解となることである.

ここで， $\alpha$ レベル集合 $L(\alpha)$ の性質 1 により， $P_{\infty}$ $\left(\hat{f}, \alpha^{1}\right)$ の最適解 $z^{1}$ と $P_{\infty}\left(\hat{f}, \alpha^{2}\right)$ の最適解 $z^{2}$ に対し て $z^{1} \leqq z^{2}$ となるので, (8) 式が活性, 即ち, 等式と して成立すれば，つぎの性質が成り立つととがわか る.

\section{[性質 2]}

$\alpha^{1}<\alpha^{2}$ に対する $P_{\infty}\left(\hat{f}, \alpha^{1}\right)$ および $P_{\infty}\left(\hat{f}, \alpha^{2}\right)$ の最 適解 $y^{1}=\left(x^{1}, z^{1}, a^{1}, b^{1}\right), y^{2}=\left(x^{2}, z^{2}, a^{2}, b^{2}\right)$ に対して (8)式が活性であれば，つぎの関係が成立する。

$$
f_{i}\left(x^{1}, a_{i}{ }^{1}\right) \leqq f_{i}\left(x^{2}, a_{i}{ }^{2}\right) \quad(i=1,2, \cdots, k)
$$

\section{3. トレード・オフ比}

本節では，ある特定の解に対する DM の判断のため 
の有力な情報となりうるトレードオフ比として 2 種類 のトレードオフ比, 即ち, 目的関数間のトレードオフ 比 $\partial f_{1} / \partial f_{i}$ と, パラメータ $\alpha$ と各目的関数間のトレー ドオフ比 $\partial f_{i} / \partial \alpha$ について考察する. まず, $P_{\infty}(\hat{f}, \alpha)$

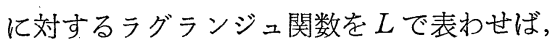

$$
\begin{aligned}
& L\left(x, z, a, b, \lambda^{f}, \lambda^{g}, \lambda^{a}, \lambda^{b}, \hat{f}, \alpha\right) \\
& =z+\sum_{i=1}^{k} \lambda_{i}^{f}\left(f_{i}\left(x, a_{i}\right)-\hat{f}_{i}-z\right) \\
& \quad+\sum_{j=1}^{m} \lambda_{j}^{g} g_{j}\left(x, b_{j}\right)+\sum_{i=1}^{k} \sum_{r=1}^{p_{i}} \lambda_{i r}^{a}\left(\alpha-\mu \tilde{a}_{i r}\left(a_{i r}\right)\right) \\
& \quad+\sum_{j=1}^{m} \sum_{s=1}^{q_{j}} \lambda_{j s}^{b}\left(\alpha-\mu \tilde{b}_{j_{s}}\left(b_{j_{s}}\right)\right)
\end{aligned}
$$

ここで, $\lambda_{i}^{f}, \lambda_{j}^{g}, \lambda_{i r}^{a}, \lambda_{j s}^{b}$ は $P_{\infty}(\hat{f}, \alpha)$ の制約式 $(8) \sim$ (11) に対応するラグランジュ乗数である. 以下では, 簡単のため, $P \propto(\hat{f}, \alpha)$ の決定変数を $y=(x, z, a, b)$ 之 置き, パラメータ $\alpha=\alpha^{*}, \hat{f}=\hat{f}^{*}$ 亿対して $P_{\infty}(\hat{f}, \alpha)$

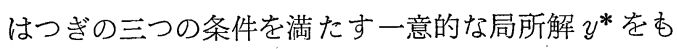
つものとする.

[仮定 1] 2 次の最適性の十分条件が成り立つ.

[仮定 2] 1 次独立制約想定が成り立つ.

[仮定 3] 狭義の相補性が成り立つ.

このとき，つぎのような感度解析における基本的な 存在定理が成り立つ12).

\section{[定理 2]}

$\alpha=\alpha^{*}$ 汶刘して, $P_{\infty}\left(\hat{f}^{*}, \alpha\right)$ は仮定 1 〜 3 を満たす 一意的な局所解 $y^{*}=\left(x^{*}, z^{*}, a^{*}, b^{*}\right)$ とそれ儿対応す るラグランジュ乗数 $\lambda^{f *}, \lambda^{9 *}, \lambda^{2 *}, \lambda^{b *}$ をつつの之す る. このとき, $\alpha^{*}$ の適当な近傍 $N\left(\alpha^{*}\right)$ に対して, $y\left(\alpha^{*}\right)=y^{*}$ (即ち $, x\left(\alpha^{*}\right)=x^{*}, z\left(\alpha^{*}\right)=z^{*}, a\left(\alpha^{*}\right)=a^{*}$, $\left.b\left(\alpha^{*}\right)=b^{*}\right), \lambda^{i}\left(\alpha^{*}\right)=\lambda^{i *}(i=f, g, a, b)$ であるような連 続的微分可能な関数 $y(\cdot), \lambda^{i}(\cdot)(i=f, g, a, b)$ が存在す る.さらに, 任意の $\alpha \in N\left(\alpha^{*}\right)$ に対して $y(\alpha), \lambda^{f}(\alpha)$, $\lambda^{a}(\alpha), \lambda^{a}(\alpha), \lambda^{b}(\alpha)$ は仮定 1 ～ 3 を満たす一意的な局所 解之対応するラグランジュ乗数である.

ここで, 定理 2 において $z(\alpha)$ は $P_{\infty}\left(\hat{f}^{*}, \alpha\right)$ の最適 值関数でああるからつぎの定理が成立する ${ }^{12)}$.

\section{[定理 3]}

定理 2 のすべての仮定が満たされてているすのとす る. とのとき， $\alpha^{*}$ の適当な近傍 $N\left(\alpha^{*}\right)$ において，つ ぎの関係式が成立する.

$$
\frac{\partial z}{\partial \alpha}=\frac{\partial L}{\partial \alpha}=\sum_{i=1}^{k} \sum_{r=1}^{p_{i}} \lambda_{i r}^{a}+\sum_{j=1}^{m} \sum_{s=1}^{q_{j}} \lambda_{j s}^{b}
$$

こてで, パラメータ $\alpha$ と目的関数 $f_{i}$ の間の関係に ついて考えてみよう. まずミニマックス問題 $P_{\infty}(\hat{f}, \alpha)$ の制約式 (8)がすべて活性 (即ち, $f_{i}\left(x^{*}, a_{i}{ }^{*}\right)-\hat{f}_{i}=$ $\left.z^{*}\right)$ であるとき, 定理 2 より， $\alpha^{*}$ の適当な近傍 $N\left(\alpha^{*}\right)$
に対して $z(\alpha)=f_{i}(x(\alpha), a(\alpha))-\hat{f}_{i}$ が成立しているの で, 定理 3 より直ちにつぎの定理が成立する.

\section{[定理 4]}

定理 2 のすべての仮定が満たされているものとす る.さらに，制約式（8) はすべて活性であるとしよ う.とのとき，つぎの関係式が成立する.

$$
\begin{gathered}
\left.\frac{\partial f_{i}}{\partial \alpha}\right|_{\alpha=\alpha^{*}}=\sum_{i=1}^{k} \sum_{r=1}^{p_{i}} \lambda_{i r}^{a *}+\sum_{j=1}^{m} \sum_{s=1}^{q_{j}} \lambda_{j s}^{b *} \\
(i=1, \cdots, k)
\end{gathered}
$$

以上のととから，(15)式により，各目的関数のパラ メータ $\alpha$ に対するトレードオフ比が求められることが わかったが，同様に仮定 $1 \sim 3$ が成立するとき，目的 関数間のトレードオフ比はつぎのように表わされるこ とが明らかにされている13.

\section{[定理 5]}

定理 2 のすべての仮定が満たされているすのとす る. また，目的関数に関する制約式（8)はすへて活性 であるとする，てのとき，次式が成立する。

$$
\left.\frac{\partial f_{1}}{\partial f_{i}}\right|_{\alpha=\alpha^{*}}=-\frac{\lambda_{i}^{f *}}{\lambda_{1}^{f *}} \quad(i=2, \cdots, k)
$$

\section{4. 対話型意思決定手法}

これまでの議論によれば，DM は，基準目的関数值 $\hat{f}$ を変化させるととにより目的関数空間における任意 の $\alpha$-パレート最適解を得るととが可能であるととあ に，あいまい性のパラメータ $\alpha$ を変化させるととに より問題のあいまいさに対応した $\alpha$-パレート最適解 を得るととも可能であるととがわかった，さらに， $\mathrm{DM}$ は,目的関数間のトレードオフ比のみならず,パラ メータ $\alpha$ と目的関数之のトレードオフ比を考虑するこ とにより, $\hat{f} や \alpha の$ 值を変更して, あいまい性を考慮 した彼の妥協解あるいは満足解を得るととが可能とな る. このようにして， $\alpha$-パレート最適解の集合の中か ら DM の妥協解あるいは満足解を導くための対話型 アルゴリズムをつぎのように構成するととができる.

ステップ1 あいまい性のパラメータ $\alpha(0<\alpha<1)$ を DM が主観的に設定して, 対応する各目的関数の 個別の最大值と最小值を計算する.

ステップ $2 \mathrm{DM}$ は，各目的関数の個別の最大值之 最小値を考慮することにより, 初期の基準目的関数值 $\hat{f}$ を設定する.

ステップ 3 設定された $\hat{f}, \alpha$ の值に対して, $P_{\infty}(\hat{f}, \alpha)$ 方解かれ, 対応する $\alpha$-パレート最適解, $\alpha$ レベル最適係数のみならず, 目的関数間のトレードオ フ比およびパラメータ $\alpha$ と目的関数とのトレードオフ 比も同時传められる. 
ステップ 4 現在の $\alpha$-パレート最適解とあいまい 性のパラメータ $\alpha$ の值に満足ならば終了，そうでなけ ればつぎに進む。

ステップ 5 現在の目的関数值とあいまい性のパラ メータ $\alpha$ の值拉よびトレードオフ比の情報を考慮し て, 基準目的関数值 $\hat{f}$ あるいはあいまい性のパラメ 一タ $\alpha$ の值を更新してステップ3へあどる.

\section{5. 数 值 例}

提案した $\alpha$-パレート最適解の概念と対話型意思決 定手法に対する理解を深めるために，係数にあいまい 性が含まれるつぎのファジィ 3 目的非線形計画問題 を考えよう。

$$
\left.\begin{array}{l}
\min \tilde{f}_{1}=\tilde{a}_{1}\left(x_{1}-9\right)^{2}+\left(x_{2}-6\right)^{2} \\
\min \tilde{f}_{2}=3 x_{1}+x_{2}-\tilde{a}_{2} \\
\min \tilde{f}_{3}=3 x_{1}+5 x_{2}-\tilde{a}_{3} \\
\text { subject to } \\
\quad g_{1}=-x_{1} \leqq 0, \quad g_{2}=-x_{2} \leqq 0
\end{array}\right\}
$$

こてで，ファジィ数 $\tilde{a}_{1}, \tilde{a}_{2} ， \tilde{a}_{3}$ はそれぞれつぎのよ うなメンバシップ関数により規定されているあのとす る.

$$
\begin{aligned}
& \mu_{1}\left(a_{1}\right)=\max \left(1-\left|a_{1}-1.2\right|, 0\right) \\
& \mu_{2}\left(a_{2}\right)=\max \left(1-2 \cdot\left|a_{2}-5.4\right|, 0\right) \\
& \mu_{3}\left(a_{3}\right)=\max \left(1-0.5 \cdot\left|a_{3}-17.1\right|, 0\right)
\end{aligned}
$$

てのとき, 対応する $\alpha$ レベル 3 目的非線形計画問題 はつぎのように定式化される.

$$
\begin{aligned}
& \min f_{1}=a_{1}\left(x_{1}-9\right)^{2}+\left(x_{2}-6\right)^{2} \\
& \min f_{2}=3 x_{1}+x_{2}-a_{2} \\
& \min f_{3}=3 x_{1}+5 x_{2}-a_{3} \\
& \text { subject to } \\
& \quad g_{1}=-x_{1} \leqq 0, \quad g_{2}=-x_{2} \leqq 0 \\
& \mu_{1}\left(a_{1}\right)=\max \left(1-\left|a_{1}-1.2\right|, 0\right) \geqq \alpha \\
& \mu_{2}\left(a_{2}\right)=\max \left(1-2 \cdot\left|a_{2}-5.4\right|, 0\right) \geqq \alpha \\
& \mu_{3}\left(a_{3}\right)=\max (1-0.5 \cdot|a-17.1|, 0) \geqq \alpha
\end{aligned}
$$

こてで, 例えば, DM が主観的に $\alpha=0.8$ と設定し たものとする．とのとき，メンバシップ值が 0.8 以上 のときのファジィ数 $\tilde{a}_{1}, \tilde{a}_{2}, \tilde{a}_{3}$ の区間を Fig. 2 亿示 す. また，各目的関数の個別の最小值はつぎのように なる。

$$
f_{1}^{\mathrm{min}}=0, f_{2}^{\mathrm{min}}=-5.5, f_{3}^{\mathrm{min}}=17.5
$$

ここで, DM は主観的に初期基準目的関数值をつぎ のように設定したとする.

$$
\left(\hat{f}_{1}, \hat{f}_{2}, \hat{f}_{3}\right)=(20,7.5,7.5)
$$

これに対して, 対応する $\alpha$-パレート最適解はつぎ の問題を解くことにより得られる.

$$
P \infty(\hat{f}, \alpha)
$$

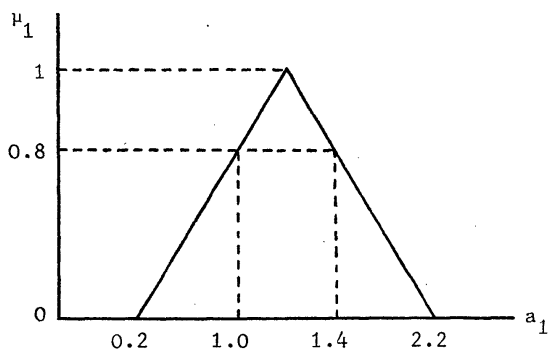

Fig. $2-1=\mu_{1}\left(a_{1}\right) \geqq 0.8$

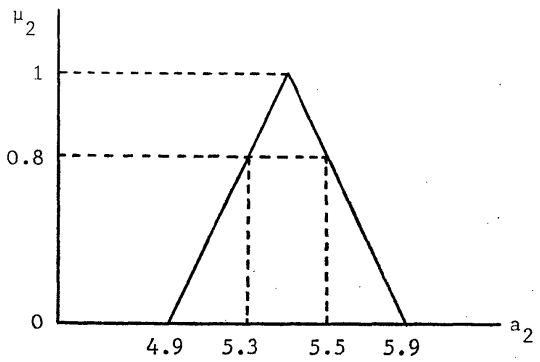

Fig. 2-2 $\mu_{3}\left(a_{2}\right) \geqq 0.8$

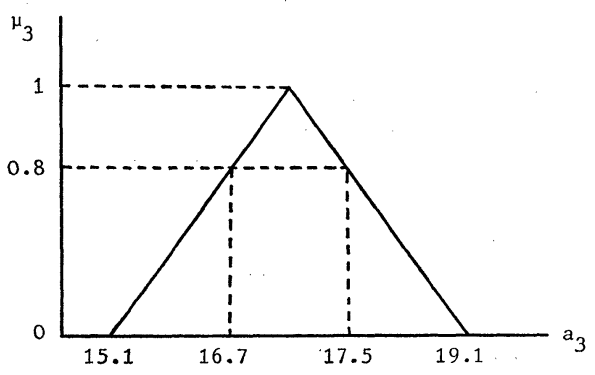

Fig. 2-3 $\mu_{3}\left(a_{3}\right) \geqq 0.8$

$\min z$

subject to

$$
\begin{array}{rr}
a_{1}\left(x_{1}-.9\right)^{2}+\left(x_{2}-6\right)^{2}-\hat{f}_{1} \leqq z \\
3 x_{1}+x_{2}-a_{2}-\hat{f}_{2} \leqq z \\
3 x_{1}+5 x_{2}-a_{3} \quad-\hat{f}_{3} \leqq z \\
-x_{1} \leqq 0 \\
-x_{2} \leqq 0 \\
\max \left(1-\left|a_{1}-1.2\right|, 0\right) \quad \geqq \alpha \\
\max \left(1-2 \cdot\left|a_{2}-5.4\right|, 0\right) \quad \geqq \alpha \\
\max \left(1-0.5 \cdot\left|a_{3}-17.1\right|, 0\right) \geqq \alpha
\end{array}
$$

このとき，仮定 1 〜 3 を満たす一意的な最適解

$$
\begin{aligned}
& \left(x_{1}^{*}, x_{2}^{*}, z^{*}\right)=(5,3,5) \\
& \left(a_{1}^{*}, a_{2}^{*}, a_{3}^{*}\right)=(1,5.5,17.5)
\end{aligned}
$$

および対応する目的関数值

$\left(f_{1}^{*}, f_{2}^{*}, f_{3}^{*}\right)=(25,12.5,12.5)$

が得られる. 制約式 (25)〜 (27)，(30)〜 (32) に対応す 
るラグランジュ乗数をそれぞれ $\lambda_{1} \sim \lambda_{6}$ とおき， $P_{\infty}$ $(\hat{f}, \alpha)$ に対するラグランジュ関数を $L$ とすれば， 2 次 の最適性の十分条件（仮定 1 ） から $\nabla L=0$ であるか ら，乙の点におけるラグランジュ乗数 $\lambda_{1}^{*} \sim \lambda_{6}^{*}$ はつぎ のように代数的に求められる.

$$
\left.\begin{array}{lll}
\lambda_{1}^{*}=3 / 11, & \lambda_{2}^{*}=1 / 2, & \lambda_{3}^{*}=5 / 22 \\
\lambda_{4}^{*}=48 / 11, & \lambda_{5}^{*}=1 / 4, & \lambda_{6}^{*}=5 / 11
\end{array}\right\}
$$

したがって，制約式(25)〜 (27) はすべて活性である ので, 各目的関数とパラメータ $\alpha$ のレードオフ比 は，定理 4 の (15) 式を適用することによりつぎのよう に求められる.

$$
\left.\frac{\partial f_{i}}{\partial \alpha}\right|_{\alpha=\alpha^{*}}=\lambda_{4}^{*}+\lambda_{5}^{*}+\lambda_{6}^{*}=\frac{223}{44} \quad(i=1,2,3)
$$

また，各目的関数間のトレードオフ比は, 定理 5 の (16)式からつぎのように求まる.

$$
\begin{aligned}
& \left.\frac{\partial f_{1}}{\partial f_{2}}\right|_{\alpha=\alpha^{*}}=-\frac{\lambda_{2}^{*}}{\lambda_{1}^{*}}=-\frac{11}{6} \\
& \left.\frac{\partial f_{1}}{\partial f_{3}}\right|_{\alpha=\alpha^{*}}=-\frac{\lambda_{3}^{*}}{\lambda_{1}^{*}}=-\frac{5}{6}
\end{aligned}
$$

$\mathrm{DM}$ は, 現在の解 (33)〜 (35) に打けるこれらのトレ ードオフ比(37)〜 (39)を考慮して, パラメータ $\hat{f} あ$ るいは $\alpha$ 更新することにより，あいまい性を考慮し た，より満足のできる解を求めるととが可能となる.

\section{6. おわりに}

現実に対象とするシステムを数式モデルとして定式 化する際には，問題に含まれる係数は，ある固定され た值传定されていると考えるよりあ，むしろ，ある あいまいな幅をあつ值であると考えた方が，より適切 に実システムをモデル化するてとができると考えられ る. てのような観点から，本論文で対象とした多目的 非線形計画問題は，その定式化において目的関数や制 約式の係数がファジィ数で表わされるあのと仮定し た. 本論文で提案した手法においては， $\alpha$ レベル集合 のあいまい性を示すパラメータ $\alpha$ と基準目的関数值を DM が設定するととにより, 係数のあいまい性を考慮 した $\alpha$ ーパレート最適解のみならず，各目的関数間の トレードオフ比书よび目的関数とパラメータ $\alpha$ のト レードオフ比が求められ，DM はこれらの情報に基づ いて $\alpha$ と $\hat{f}$ 更新するととにより, 彼の満足解を求め ることができる．乙こで，パラメータ $\alpha$ の更新に際し ては, 特に，つぎの点に注意する必要がある. 即ち, 性質 2 からあ明らかなように， $\alpha$ をより小さく設定す れば，ある固定された基準目的関数值 $\hat{f}$ に対してより よい解が得られることが期待されるが，しかし一方， 逆にそれだけ設定された問題の現実性の度合いが薄れ
るものと考えられるので，DM はこれらの間のバラン スを考慮してパラメータ $\alpha$ を設定しなければならない ということである。したがって，DM はある目的関数 を改善するためには，他のいずれかの目的関数を犠牲 にせざるを得ないことのみならず，問題の現実性の度 合を高めれば, 目的関数の值が悪くなることも考慮す る必要がある，なお，本論文では， $\alpha$-パレート最適解 の概念之対話型意思決定手法の考え方を簡単な数值例 により例示したが，今後，現実の問題を設定する立場 にある専閒家達との協力により，実際の意思決定状況 を十分に反映させたファジィパラメータを含む多目的 非線形計画問題を定式化するととあに, 現実に意思決 定を行う立場にある人々と協力した応用例をつみ重ね るととにより，提案した手法の改良が行われるべきで あろう. 最後に，本論文で提案した $\alpha$ レベル集合を適 用した $\alpha$-パレート最適解の概念之，拡張原理に基づ くファジィ数間の大小関係を適用して得られるであろ うパレート最適解の抬張概念之の間には，密接な関係 があるあのと思われるが，乙れらのととに関する詳し い考察は稿を改めて行う予定である.

\section{参 考 文 献}

1) H. J. Zimmermann : Fuzzy Programming and Linear Programming with Several Objective Functions, Fuzzy Sets and Systems, 1-1, 45/55 (1978)

2) H. J. Zimmermann : Using Fuzzy Sets in Operational Research, European Journal of Operational Research, 13-3, 201/216 (1983)

3) 坂和: 多目的線形計画問題に対する対話型ファジィ意思 決定手法之その応用，電子通信学会論文誌，J65-A-11， 1182/1189 (1982)

4) 坂和, 湯峯: 多目的線形分数計画問題に対する対話型 アジィ意思決定，システムと制御，27-2，138/146 (1983)

5) 坂和：線形システムの最適化〈一目的加ら多目的へ〉, 森 北出版 (1984)

6) 坂和, 湯峯, 矢野: 多目的非線形計画問題に対する対話 型ファジィ満足化手法, システムと制御, 28-10, 575/582 (1984)

7）田中, 浅居：ファジイ関数による線形計画問題の定式化, システム之制御， 25-6，351/357 (1981)

8) 田中, 市橋, 浅居: ファジィ目的関数によるファジィ線 形計画問題の定式化, Journal of the Operations Research Society of Japan, 27-2, 178/189 (1984)

9) S. A. Orlovski: Multiobjective Programming Problems with Fuzzy Parameters, Control and Cybernetics, 13-3, 175/183 (1984)

10) D. Dubois and H. Prade: Operations on Fuzzy Numbers, International Journal of Systems Science, 9-6, 613/626 (1978)

11) D. Dubois and H. Prade: Fuzzy Sets and Systems: Theory and Applications, Academic Press (1980)

12）福島：非線形最適化の理論, 産業図書 (1980)

13）矢野, 坂和: 重みづけチェビシェフノルム法におけるト レードオフ比, 計測自動制御学会論文集, 21-3，248/255 (1985) 